\title{
Service Selection Strategy in Car Maintenance Using Product Service System (PSS) and Quality Function Deployment (QFD)
}

\author{
Gilang Megantara \\ Management of Technology Department \\ Institut Teknologi Sepuluh Nopember \\ Surabaya, Indonesia
}

\author{
Mokh. Suef \\ Management of Technology Department \\ Institut Teknologi Sepuluh Nopember \\ Surabaya, Indonesia
}

\begin{abstract}
Product bundling is a strategy by selling two or more products in one package and one price. Bundling has become an effective and profitable strategy. But bundling must still meet the needs of consumers themselves. In this study, the researcher attempted to create a desired service by combining available services and products into a bundling / service pack with the Product Service System (PSS) and Quality Function Deployment (QFD) method to fullfil the consumer's wishes. The 10 factors of purchase are cost, quality, variance, innovation, extra care, practical and efficient, brand image, prizes, promotions / discounts, and trends, from 35 respondents have interest rate at cost (3.94), quality (3.88) , 3.23), practical and efficient (3.34), brand image (2.22), prizes (3), promotions / discounts (3.65), and trends (1.8). From the voice of customer or consumer desire then made some bundling PSS to be able to meet consumer desires. Among fix murmer, fix pasti asli, fix canggih, fix tahun baruan, fix santai, fix ketolong, fix nyaman, fix bersih, fix LCGC, fix sejuk, fix total, fix aman, fix radiator. From the weighting results obtained 10 bundling PSS to be tested in relation to the fulfillment consumers needed by looking at the relationship between consumer desires and bundling PSS offered by the company with the QFD method. From the results of processing and research, the results are fix murmer $(11.7 \%)$, fix pasti asli (14.1\%), fix canggih (7.4\%), fix tahun baruan (9.4\%), fix santai (10.8\%), fix ketolong (4.7\%), fix nyaman (11.2\%), fix bersih $(9.9 \%)$, fix LCGC $(14.8 \%)$, dan fix total $(6.1 \%)$. The conclusion that PSS bundling Fix LCGC becomes an option to be proposed as a bundling of PSS that can satisfy the consumer's desire with a value of $14.8 \%$ of all PSS bundling tested.
\end{abstract}

Keywords - Product and Service System; Quality Function Deployment; PSS; QFD; Product; Service.

\section{INTRODUCTION}

Product bundling is a strategy that selling two or more products in one package and one price. Bundling has become an effective and profitable strategy in many circumstances. There are several reasons why companies do bundling products such as cost efficiency, market opportunities to increase profits, and competitive strategies. The benefit of bundling is package has more value than the number of each unit, bundling provides simplicity and ease in choosing among various options, bundling can solve problems for consumers, bundling is usually complementary to be more useful, bundling can attract attention or even controversy. In this study collaboration with a vehicle maintenance service provider company, trying to find out consumers needs through a questionnaire, or ussually called the voice of customer. The company try to provide car maintenance services to suit the consumers' wishes. So in this research will use Product Service System (PSS) method and supported by Quality Function Deployment (QFD) to test the strength of relation between consumer desire (needs) and solution offered (hows). With so expected the company can provide car maintenance services that meet the criteria of consumer desires. Another advantage of bundling these products and services is increased cost efficiency, increased profits and the ability of companies to survive in the automotive business competition.

\section{A. Product Service System}

\section{METHODOLOGY}

Product and Service System (PSS) is a business model that provides products and services in a cohesive manner. The PSS model emerges as a means to enable collaborative consumption of products and services (Piscicelli, 2015). A product and service system can be defined as an intangible product and an intangible service combined into an entity that can meet consumer needs well (Tischner U, 2002).

Unlike traditional product-focused, PSS combines products and services to meet consumer needs. PSS can also be called a smart product (Cees Van Halen., 2005).

\section{B. Quality Function Deployment}

Quality Function Deployment (QFD) is also known as quality house. Initially QFD was created in 1966 in Japan to help transform the voice of customer (VOC) into product characteristics that will be developed by the engineer (Akao, 1994). According to Dr. Yoji Akao (1994) a method for transforming user requests into a design quality to spread function forming quality and deploy methods to achieve design quality into systems, component parts, and specific elements in the manufacturing process. VOC is a term used to symbolize the process of finding out what consumers really want or expect about a product. VOCs are usually used when creating new products.

\section{Product}

Products are goods or services that can be traded. In marketing, a product is anything that can be offered to a market and can satisfy a desire or need (Kotler, 2008). In the retailer level, the product is often referred to as a merchandise. In manufacturing, products are purchased in the form of raw goods and sold as finished goods. Products in the form of raw goods such as metal or agricultural products are often referred to as commodities. 


\section{Service}

Excellent service to consumers is a must if we do not want to be shifted from the competitive world of business. Increasingly savvy consumer behavior has put the quality of service at the top of the line beating the quality of products / services in terms of consideration to use / purchase of goods / services. Moreover, the current access to consumer complaints has been widespread, if initially only on a complaint letter posted on the company, the current consumer complaints can be written anywhere. Starting from national newspapers, mailing lists, and various other social media. Of course, if one consumer alone is disappointed with the service provided, the news will quickly spread so widely that it can be fatal for the entrepreneur itself.

\section{E. Business Strategy}

This business strategy is often called a functional business strategy because it is oriented to management activities, such as marketing strategies, production or operational strategies, distribution strategies, organizational strategies, resource management strategies and strategies related to financial management.

\section{RESULT AND DISCUSSION}

Through questionnaire then performed data processing to get importance to customer value, make PSS design, look for SWOT and excellence of each PSS design, up to HOQ manufacture and produce one product and service proposal that can be considered to be applied.

\section{A. Collecting Data}

Qualitative data collection is done by giving questionnaire to consumer. Questionnaire consists of 10 questions relating to the desire of consumers, ranging from economic factors to technical factors obtained from the results of interviews and observations in the field.

Table 1. Questionnaire Atribute

\begin{tabular}{|c|c|c|}
\hline No & Atribute & Questions \\
\hline 1 & Less Cost & $\begin{array}{c}\text { Cheaper Costs Package products and } \\
\text { services at a lower cost affect you in } \\
\text { buying }\end{array}$ \\
\hline 2 & Quality & $\begin{array}{c}\text { Quality Package quality products and } \\
\text { services affect you in buying }\end{array}$ \\
\hline 3 & $\begin{array}{c}\text { Variants number of product and } \\
\text { service variants becomes one of the } \\
\text { factors that influence buying these } \\
\text { products and services }\end{array}$ \\
\hline 4 & Innovation & $\begin{array}{c}\text { Innovative products and services are } \\
\text { an influence in buying a product }\end{array}$ \\
\hline 5 & Extra Maintenance & $\begin{array}{c}\text { Extra Care Packages Packages of } \\
\text { products and services that can give } \\
\text { more care to your vehicle }\end{array}$ \\
\hline 7 & Practical \& Efficient & $\begin{array}{c}\text { Practical and Efficient Practical and } \\
\text { efficient products and services (eg } \\
\text { booking and home service) }\end{array}$ \\
\hline 8 & Prizes & $\begin{array}{c}\text { Brand image The product image / } \\
\text { brand affects your purchases }\end{array}$ \\
\hline 9 & Promotion & $\begin{array}{c}\text { Prizes Whether the services and the } \\
\text { prize products affect you in making a } \\
\text { purchase }\end{array}$ \\
\hline 10 & Trend & $\begin{array}{c}\text { Trend Do you buy trendy products and } \\
\text { services (teflon coating, anti-rust, } \\
\text { ceramic coating) }\end{array}$ \\
\hline
\end{tabular}

In this research, create a PSS design by combining product and service, in Table 2 and Table 3 the list of product and service

Table 2. Product list

\begin{tabular}{|c|c|}
\hline \multicolumn{2}{|c|}{ Table 2. Product list } \\
\hline No. & Produk / Suku Cadang \\
\hline 1 & Engine Oli ( Mineral, Semi sintetis, full sintetis ) \\
\hline 2 & Automatic Oli (Manual, Otomatis) \\
\hline 3 & Axle Oli \\
\hline 4 & Brake Fluid \\
\hline 5 & Engine Flush \\
\hline 6 & Injector Cleaner \\
\hline 7 & Brake Cleaner \\
\hline 8 & Radiator Flush \\
\hline 9 & Radiator Coolant \\
\hline 10 & Nitrogen \\
\hline 11 & Spark \\
\hline 12 & Air Filter \\
\hline 13 & Oil Filter \\
\hline 14 & Cabin Filter \\
\hline 15 & Fuel Filter \\
\hline 16 & Brake Part \\
\hline 17 & Suspension \\
\hline
\end{tabular}

Table 3. Service list

\begin{tabular}{|c|c|}
\hline No. & Jasa \\
\hline 1 & Oil Change \\
\hline 2 & Engine Tune Up \\
\hline 3 & Brake Cleaning \\
\hline 4 & Home service \\
\hline 5 & Emergency \\
\hline 6 & Part Changing \\
\hline 7 & Computer Diagnostic \\
\hline 8 & Checkup \\
\hline 9 & Air Conditioner Maintenance \\
\hline 10 & Tire Rotation \\
\hline
\end{tabular}

\section{B. Product Service System (PSS)}

The data obtained then processed into a PSS design, PSS design is used to meet the desires of consumers in a service. There is 13 pss designs proposal in this research.

\section{SWOT Analysis}

From 13 proposed pss designs will be made swot analysis, then from 13 pss the design is reduced to 10 pss designs to be proposed and tested into the house of quality (HOQ). 


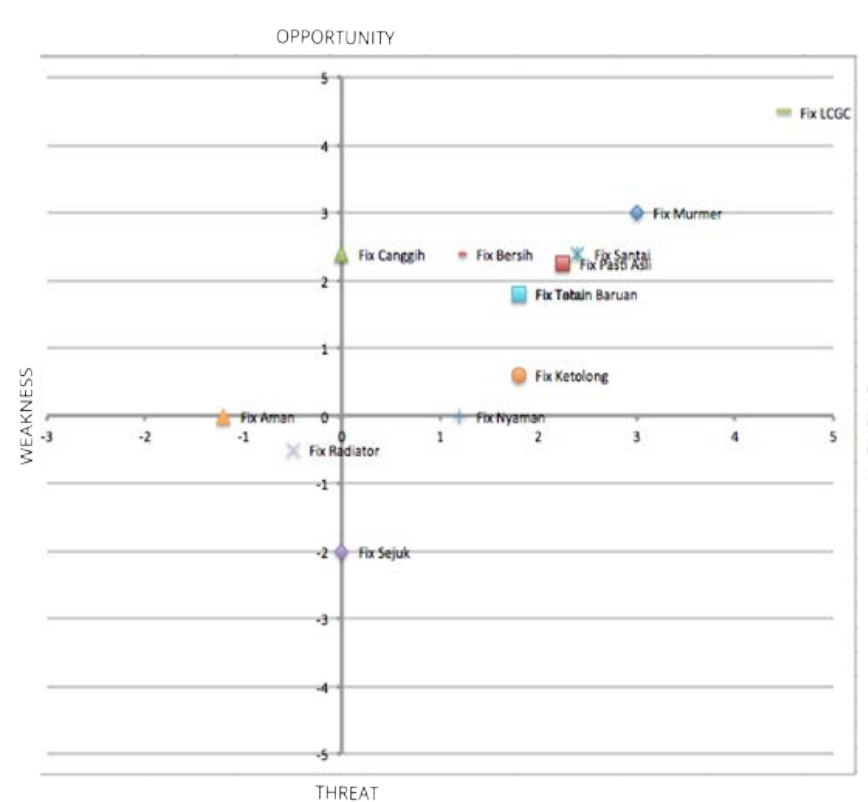

Image 1. SWOT Quadrant Analysis

\section{Quality Function Deployment (QFD)}

By using House of Quality the result to get the intersection between the desire of consumers with the ability of the company to be able to meet the needs of consumers.

\section{CONCLUSIONS}

1. Based on the result of analysis by using HOQ, the company suggested to present the service of Fix LCGC that is special treatment for small cc vehicle or LCGC with highest proportion value from 10 other PSS proposal that is $14.8 \%$.

2. Providing quality original products, since the majority of consumers still want genuine products with value to customer $26 \%$ and with fixed fixed service with the second highest $14.1 \%$ percentage value of 10 PSS proposed.

\section{REFERENCE}

[1] Piscicelli, L. C. (2015). The role of values in collaborative consumption: Insight from a product-service system for lending and borrowing in the UK. Journal of Cleaner Production.

[2] Tischner U., V. M. (2002). First draft PSS review. Cologne, Germany: SusProNet Report.

[3] Cees Van Halen., C. V. (2005). Methodology for Product Service System Innovation. Assen: Uitgeverij Van Gorcum , 21.

[4] Akao, Y. (1994). Development History of Quality Function Deployment. The Customer Driven Approach to Quality Planning and Deployment. 